\title{
Prologue: Juvenility Inferences of Parental Advance Aging
}

\author{
Aamir Javed 1*, Stephen Yesudhas', Divya Agarwal'2, Rudradatta Shrotriya ${ }^{3}$ \\ ${ }^{1}$ Morpheus Life Sciences Pvt Ltd \#352, Bengaluru, India \\ ${ }^{2}$ Ayushman Hospital, Varanasi, India \\ ${ }^{3}$ Ashok Nagar Society, Mumbai, India \\ Email: *aamir.javed@morpheusivf.com
}

How to cite this paper: Javed, A., Yesudhas, S., Agarwal, D. and Shrotriya, R. (2018) Prologue: Juvenility Inferences of Parental Advance Aging. Advances in Reproductive Sciences, 6, 109-112. http://dx.doi.org/10.4236/arsci.2018.63009

Received: July 20, 2018

Accepted: August 18, 2018

Published: August 21, 2018

Copyright (c) 2018 by authors and Scientific Research Publishing Inc. This work is licensed under the Creative Commons Attribution International License (CC BY 4.0).

http://creativecommons.org/licenses/by/4.0/

\section{(c) (i) Open Access}

\begin{abstract}
Couples are escalating delay in childbearing to the late $35 \mathrm{~s}$ (female), the $40 \mathrm{~s}$ (males) and afar. The surmising of this collective and societal transformation on youth constitution and salubriousness has just at present been a spotlight of research. There are distinguished intensified perinatal risks related with expanding maternal age, notwithstanding the way that fatherly age seems to have a presumably predominant adverse impingement on youth well-being. Although the preeminent rate of poor gravidness consequence may contrast from individual to singular point of view, the impingement of postponing childbearing from a general wellbeing perspective cannot be swelled and should be in the pattern of general wellbeing plan for the coming years. Recognizing the part of components and black box, characteristically the maturing of the gametes, and how this change effects on preparation, blastulation lastly the posterity, is an essential and consequent advance as we attempt to help patients outline sound families.
\end{abstract}

\section{Keywords}

Advanced Maternal Age, Advanced Paternal Age, Adverse Neonatal Outcome, Prematurity

\section{Introduction}

Many authors superscribed the communal and societal delay in childbearing from the maternal outlook. However, we spotlight on the impingement of parental age both maternal and paternal on the health of the newborn [1]. Every one of us who rehearse in the field of barrenness frequently invests divine energy and exertion pondering how to enhance achievement rates and accomplish 
pregnancies and seldom do we lengthen our sight afar the live birth. These perspectives and arrangement will take a gander at the effect of parental maturing on youth well-being and prosperity and start to understand the potential systems of an unfavorable impact. The latest National Key Measurements Report [2] recommends that parental age has been continuously expanding. Fatherly age for which specifically regarding neuropsychiatric peril, expanding fatherly age is proportional with higher youth chance [3].

The science of the oocyte and sperm is moreover extraordinary and may represent at any rate some of these distinctions [4]. They may likewise recommend potential dangers that require advance cautious long haul perception and follow-up of youngsters destined for more established guardians. It is outstanding that mitochondria are maternally determined. New systems endorsed in Europe for medicines of mitochondrial malady have raised moral issues because of the adjustment in germ-line legacy by substituting benefactor mitochondria for influenced mitochondria of the hereditary and planned mother [5]. We additionally realize that mitochondrial DNA (mtDNA) isn't equipped for DNA repair and is therefore at more severe danger of getting changes with age. The current month's perspectives and surveys segment show a contention for how expanded maternal age may affect the life expectancy of the kids inferable from expanded mtDNA changes and the non-Mendelian germ line legacy from the mother. What's more, although that the more significant part of chromosomal aneuploidies get from modifications in oocyte meiosis and, less thus, mitosis; sperm DNA is additionally subject to nondisjunction, on the grounds that spermatogonial undeveloped cells partition for the duration of the life of the male with replication, and hazard for a blunder, going before every division [6]. Although the cutoff for "fatherly propelled age" isn't unmistakably characterized, there is an expansion in hereditary hazard as men age more than 48 [7]. What's more, this hazard likely reaches out past the expansion in neuropsychiatric hazard to the posterity.

So how would we guide couples? It is farfetched that the mongrel lease slant in deferred childbearing will invert. For ladies, the expanded danger of irregular birth cycle and chromosomal aneuploidy related with expanded age is all around recorded. Furthermore, instead of men, ladies are conceived with every one of the eggs they will ever have, and this "pool" is logically exhausted with maturing. Our capacity to evaluate "ovarian save," with the utilization of apparatuses, for example, antral follicle check and hostile to the anti-mullerian hormone, has enhanced, yet despite everything, we cannot foresee the rate of misfortune for an individual lady [8]. Ladies are looked with both declining amount and declining nature of oocytes with maturing [9]. Alongside enhancements in innovation allowing fruitful oocyte cryopreservation, has prompted an emotional increment in young ladies solidifying oocytes to save ripeness. Albeit early achievement rates with this innovation give off an impression of being high, the effect of age on oocyte survival and hereditary ordinariness, and a definitive utilization of 
these oocytes, is as yet not known. Be that as it may, even this innovation will not modify the expanded perinatal dangers related with cutting-edge maternal age should ladies utilize this "protection strategy" to postpone childbearing into their $40 \mathrm{~s}$, the same number of the plan to do. It is an occupant upon us as doctors to guide patients concerning these dangers and that the cryopreserved oocytes speak to just potential for progress and not an "infant" in the cooler [10].

Shouldn't something be said about the dangers related with fatherly maturing? As found in the present Perspectives and Audits, the hazard for neuropsychiatric scatters, and hazard for certain chromosomal blunders and a potential relationship with expanded lifetime growth chance, have been related to expanding fatherly age [11]. However, the total dangers are still less. In this way, even though guiding of our couples about these dangers would be fitting, the hazard does not appear to ascend to the level that would recommend men ought to solidify sperm at a youthful age exclusively to decrease this hazard. In addition to the fact that this is likely a bit much, but preferably we have to consider the upkeep of expanding gamete stockpiling for drawn-out stretches of time. The suggestions for programs, and for the people who cryopreserve, are not little.

\section{Conclusion}

A synopsis, parental age significantly affects posterity. In any case, so do as numerous such things that men and ladies can do before a pregnancy, amid a pregnancy, and amid kid raising [12]. Urging patients to keep up a substantial way of life, to not uncover themselves or their kids to natural toxicants, and to be "available" amid their youngster's instruction and life would likely do significantly more to enhance general youth prosperity [12]. That being stated, we have to keep on investigating the fundamental systems of gamete maturing and its suggestions. Furthermore, we have to take a long haul perspective of "progress" as we watch over couples looking for our help.

\section{Conflict of Interests}

The authors declare that they have no conflict of interests.

\section{References}

[1] Kenny, L.C., Lavender, T., McNamee, R., O’Neill, S.M., Mills, T. and Khashan, A.S. (2013) Advanced Maternal Age and Adverse Pregnancy Outcome: Evidence from a Large Contemporary Cohort. PLoS One, 8, e56583. https://doi.org/10.1371/journal.pone.0056583

[2] Martin, J.A., Hamilton, B.E., Osterman, M.J., Curtin, S.C. and Matthews, T.J. (2015) Births: Final Data for 2013. National Vital Statistics Reports, 64, 1-65.

[3] Schimmel, M.S., Bromiker, R., Hammerman, C., Chertman, L., Ioscovich, A., Granovsky-Grisaru, S., et al. (2015) The Effects of Maternal Age and Parity on Maternal and Neonatal Outcome. Archives of Gynecology and Obstetrics, 291, 793-798. https://doi.org/10.1007/s00404-014-3469-0

[4] Balasch, J. and Gratacos, E. (2012) Delayed Childbearing: Effects on Fertility and 
the Outcome of Pregnancy. Current Opinion in Obstetrics and Gynecology, 24, 187-193. https://doi.org/10.1097/GCO.0b013e3283517908

[5] Amato, P., Tachibana, M., Sparman, M. and Mitalipov, S. (2014) Three-Parent in Vitro Fertilization: Gene Replacement for the Prevention of Inherited Mitochondrial Diseases. Fertility and Sterility, 101, 31-35. https://doi.org/10.1016/j.fertnstert.2013.11.030

[6] Bayrampour, H. and Heaman, M. (2010) Advanced Maternal Age, and the Risk of Cesarean Birth: A Systematic Review. Birth, 37, 219-226. https://doi.org/10.1111/j.1523-536X.2010.00409.x

[7] Kovac, J.R., Addai, J., Smith, R.P., Coward, R.M., Lamb, D.J. and Lipshultz, L.I. (2013) The Effects of Advanced Paternal Age on Fertility. Asian Journal of Andrology, 15, 723-728. https://doi.org/10.1038/aja.2013.92

[8] Kirz, D.S., Dorchester, W. and Freeman, R.K. (1985) Advanced Maternal Age: The Mature Gravida. American Journal of Obstetrics \& Gynecology, 152, 7-12. https://doi.org/10.1016/S0002-9378(85)80166-6

[9] Blomberg, M., Tyrberg, R.B. and Kjølhede, P. (2014) Impact of Maternal Age on Obstetric and Neonatal Outcome with Emphasis on Primiparous Adolescents and Older Women: A Swedish Medical Birth Register Study. BMJ Open, 4, e005840. https://doi.org/10.1136/bmjopen-2014-005840

[10] Başer, E., Seçkin, K.D., Erkilinç, S., Karsli, M.F., Yeral, I.M., Kaymak, O., et al. (2013) The Impact of Parity on Perinatal Outcomes in Pregnancies Complicated by Advanced Maternal Age. Journal of the Turkish-German Gynecological Association, 14, 205-209. https://doi.org/10.5152/jtgga.2013.62347

[11] Shaikh, F., Wagan, F., Jillani, K. and Memon, K. (2012) Pregnancy Outcome at Maternal Age 40 and Older. Journal of the Liaquat University of Medical and Health Sciences, 11, 139-142.

[12] Wang, Y., Tanbo, T., Åbyholm, T. and Henriksen, T. (2011) The Impact of Advanced Maternal Age and Parity on Obstetric and Perinatal Outcomes in Singleton Gestations. Archives of Gynecology and Obstetrics, 284, 31-37. https://doi.org/10.1007/s00404-010-1587-x 